\title{
BIMBINGAN FIQIH SHOLAT KHUSYUK DI MASJID DARUL ARQOM DESA BATURINGGIT KECAMATAN SEKARBELA KOTA MATARAM
}

\author{
Saprun1, Mappanyompa ${ }^{2}$ \\ 1Program Studi PGMI, 2Program Studi KPI, Universitas Muhammadiyah Mataram, Indonesia \\ Saprunnabil5@gmail.com ${ }^{1}$, Mayompakaltim@gmail.com ${ }^{2}$
}

\begin{tabular}{l} 
INFO ARTIKEL \\
\hline Riwayat Artikel: \\
Diterima: 02-05-2021 \\
Disetujui: 30-10-2021 \\
\hline
\end{tabular}

Kata Kunci:

Bimbingan,

FiqihSholat,

Khusyu'

Keywords:

Guidance,

Fiqh Prayer,

Khusyu'

\begin{abstract}
ABSTRAK
Abstrak:

Sholat itu memiliki kedudukan yang mulia didalam islam, bahkan sholat itu dijadikan sebagai tiang agama di dalam agama islam, artinya seseorang tidaklah dikatakan muslim manakala ia meninggalakan sholat, sebagaimana disebutkan didalam hdits Nabi yang masyhur "pokok segala urusan adalah islam, sedangkan tiangnya adalah sholat dan puncak perkaranya adalah jihad. Shalat merupakan kewajiban yang diwajibkan bagi setiap muslim yang baliq dan berakal. Penelitian yang penulis lakukan adalah penelitian lapangan (field research) yang pengumpulan datanya dilakukan secara langsung dari lokasi penelitian. Data-data penelitian ini diperoleh langsung dari jama'ah sholat di Masjid Darul Arqom Baturinggit Kecamatan Sekarbele menggunakan observasi, wawancara, dan dokumentasi Data-data yang dikumpulkan dianalisis dengan menggunakan teknik analisis interaktif Model Miles dan Huberman yang meliputi reduksi data, menyajikan data, hingga memverifikasi dan menyimpulkan data, Adapun hasil penelitian ini adalah: pelatihan sholat khusyuk dengangan kitab 33 sebab yang menghantarkan kehusyukan di dalam sholat yang ditulis oleh Dr. Al-Munajjid berdampak sangant baik pada perubahan tatacara sholat, bacaan sholat dan perubahan sikap jama'ah seusai mempraktekkan gerakan sholat yang sesuai dengan tuntunan Rosul Sholallahu 'alaihi Wasallam. Maka berdasarkan hasil penelitian ini dapat disimpulkan bahwa pelatihan shalat khusyuk memiliki pengaruh positif dalam ritual ibadah sholat para peserta pelatihan di Masjid Daru Arqom.

Abstract:

Prayer has a noble position in Islam, even prayer is used as a pillar of religion in Islam.Itmeans that a person is not said to be a Muslim when he leaves the prayer. as mentioned in the famous hadith of the Prophet "the subject of all affairs is Islam".while the pillar is prayer and the peak of the matter is jihad. Prayer is an obligation that is obligatory for every Muslim who is baliq and reasonable.The research that the author does is field research, where data collection is carried out directly from the research location.The data of this study were obtained directly from the prayer congregations at the Darul Arqom Mosque Baturinggit, Sekarbele District using observations, interviews,collected were analyzed using the Miles and Huberman Model interactive analysis technique which includes data reduction, data presentation,to verify and conclude the data, The results of this study are:training in solemn prayer with the book of 33 reasons that lead to solemnity in prayer written by Dr. Al-Munajjid had a very good impact on changing prayer procedures,prayer readings and changes in the attitude of the congregation after practicing prayer movements in accordance with the guidance of the Prophet Sholallahu 'alaihi Wasallam. So based on the results of this study it can be concluded that the solemn prayer training has a positive influence on the prayer rituals of the trainees at Daru Arqom Mosque.
\end{abstract}

\section{A. LATAR BELAKANG}

Manusia sebagai makhluk yang paling istimewa dibandingkan dengan makhluk yang lainnya, bahkan Alloh istimewakan dalam penciptaannya dan dikaruniai kebebasan memilih dalam kehidupannya, menjadi suatu acuan bahwa memang manusia diberi kebebasan memilih apaapa yang akan dilakukan dalam hidupnya, maka dalam kitab suci Al-Quran akan ditemukan banyak sekali perintah beserta larangan dari Allah SWT yang tertuju khusus bagi seorang hamba.
Sebab itu, manusia hendaklah menimbang apapun yang akan ditunaikan karena berbagai resikonya akan hadir di dalamnya, sebagai suatu upaya dari distorsi arah kehidupan yang benar, bahkan hendaknya seorang hamba menjadikan seluruh aktivitasnya sebagai wujud ibadah kepada Allah SWT, demikian agar seseorang tiada terlepas kontak dari Sang Penciptanya. salah satu upaya menjaga hubungan kontak dengan Allah SWT adalah dengan melaksanakan sholat, sehingga bermula dari sinilah pengaruh amalan terbentuk, 
termasuk rasa bahagia yang sangat diinginkan seluruh manusia.

Sholat merupakan ibadah yang Alloh wajibkan bagi seluruh umat islam di dunia. Salah satu aspek agama ini telah menjiwai seluruh umat yang menunaikannya, meskipun sekilas tak kasat mata, terlebih manusia yang hanya mampu menilai secara fisik, sebuah mata akan segera tertipu oleh penilaian yang tidak konkret, karena ini bukan perihal fisik tetapi metafisik. Hal demikian yang dinamakan khusyu', ialah yang menjadi patokan seseorang dalam pelaksanaannya dengan penuh kesungguhan atau hanya sekedar melaksanakan kewajiban (Hukum et al., 2017).

Khusyu' dalam sholat pun bukan sekedar kewajiban tetapi juga kebutuhan. Selagi manusia merupakan makhluk yang lemah tanpa daya bantuan keajaiban serta keridhoan, ia bak kerdil nan mungil yang sejatinya sangatlah kecil dihadapan Sang Ilahi(Suri, 2014). Maka dengannya, seseorang butuh meluapkan semua yang tersimpan dalam lubuk hatinya agar lekas melahirkan ketenangan yang luar biasa lepas landas dari kejenuhan dan kejumudan yang melanda hatinya.

Lantas, apakah sholat dengan kebahagiaan atau ketenangan memiliki keterkaiatan antara satu dengan yang lainnya? Bagaimana bisa dari ibadah sholat saja lahirlah kebahagiaan? Maka benarlah apa yang disabdakan Nabi dalam sebuah hadits yang berbunyi: "wahai bilal kita tenang (bahagia) di dalam sholat" beliau Nabi Muhammad tidak mengatakan kita tenang atau bahagia dengan sholat itu namun bahagia, senang, dan tenag di dalam sholat.

Sholat yang Khusyu' merupakan hal yang menjiwai shalat, dimana darinya akan berpengaruh pada kehidupan seseorang, Shalat sendiri secara etimologi memiliki arti doa, rahmat, dan menurut syariat islam, sholat dimaknai beberapa ucapan dan perbuatan yang diawali dengan takbiratul ihram dan diakhiri dengan salam, Sedangkan secara terminology kata shalat memiliki makna perwujudan rasa bakti, tunduk dan patuh serta secara bathiniah dan jasmaniah memuliakan Allah SWT dan dilakukan dalam keadaan yang penuh etika dan estetika(Hidayah, 2021).

Kata khusyu', dalam Al-Quran sendiri telah disebutkan sebanyak tujuh belas kali, dengan arti mendasarnya adalah tunduk, takluk dan rendah diri. Dalam Surah Al-Mukminun menjelaskan bahwa khusyu' dalam shalat merupakan salah satu sifat orang-orang yang beriman, dengan maksud sikap diam dan tenang, sedangkan bagi M. Quraish Shihab jelasnya khusyu' merupakan kesan khusus dalam hati yang khusyu' terhadap apa yang ia tuju sehingga terarah betul kepadaNya seraya mengabaikan selainNya. Sebagian ulama pun ikut memberi penjelasan bahwa khusyu' dalam hal ini sebagai bentuk rasa takut dari tidak diterimanya shalat(Romadhon, 2019).

Menurut Al-Ghazali dalam kitab Ihya' Ulum alDin menyatakan, bahwa khusyu' mencakup enam hal yakni, kehadiran hati, mengerti antara yang dibaca dan yang diperbuat, mengagungkan Allah SWT, serta merasa malu terhadap-Nya. Keseluruhannya disatukan dalam satu titik temu yaitu melaksanakan sholat. Meminjam istilah Ahmad Zaki Mubarak, definisi ini mengajak umat untuk mendidik jiwa dan kefitrahan seorang manusia.

Dalam pengertian lain, menurut Syekh Ala'udin Ali bin Muhammad bin Ibnu Baghdadi menyebutkan bahwa khusyu' dalam shalat merupakan wujud perpaduan konsentrasi jasad dengan hati serta berpaling dari hal-hal selain Allah SWT, memaknai setiap bacaan yang dilafazhkan. Sehingga khusyu' dalam sholat merupakan wujud dari lahiriah dan bathiniah, karena antara jasad dan hati semua harus tertuju penuh penghayatan dan penghambaan kepada Sang Khaliq Yang Maha Satu.

\section{B. METODE PENELITIAN}

Penelitian ini adalah penelitian lapangan (field research) yang berusaha melihat realitas praktis bimbingan fiqih sholat khusyuk' di masjid BaitulArqam. Penelitian ini termasuk kualitatif deskriptif maka peneliti akan memanfaatkan datadata kualitatif kemudian dijabarkan secara deskriptif. Peneliti untuk melakukan observasi, yang mana observasi ini merupakan sebuah teknik yang dilakukan lewat pengamatan langsung. Peneliti melakukan pengamatan di tempat objek penelitian untuk diamati menggunakan pancaindra. Peneliti dalam hal ini diposisikan sebagai pengamat atau orang luar.

Dalam mengumpulkan data menggunakan observasi, peneliti dapat menggunakan catatan maupun rekaman. Observasi dapat bersifat partisipatoris, yaitu ketika peneliti turut bergabung dan melakukan aktivitas bersama objek pengamatannya.

Wawancara merupakan salah satu metode yang paling banyak digunakan para peneliti untuk mengumpulkan informasi dan data. Dengan wawancara, seseorang bisa mendapatkan berbagai macam informasi yang dibutuhkan. Agar bisa mendapatkan informasi yang dibutuhkan, 
pewawancara harus mengetahui langkah-langkah, etika, dan jenis wawancara(Arifin, 2018).

Secara umum, wawancara atau interview adalah tanya jawab antara dua pihak yaitu pewawancara dan narasumber untuk memperoleh pendapat, keterangan, dan data. Biasanya, wawancara digunakan untuk mendapatkan informasi yang berhubungan dengan fakta, kepercayaan, perasaan, dan keinginan yang diperlukan untuk memenuhi tujuan penelitian(Purahman, 2018).

Wawancara sendiri dibedakan menjadi beberapa jenis, yaitu berdasarkan cara pelaksanaan, jumlah narasumber, dan keterbukaan informasi. Di mana beberapa jenis wawancara tersebut memiliki cirinya masing-masing dan studi dokumen untuk mendapatkan data. Observasi dimana peneliti terlibat secara langsung di dalam bimbingan sholat khusyuk' di masjid Darul Arqom desa baturinggit kecamatan sekarbela. Sedang interview dilakukan kepada peserta langsung dalam hal ini jama'ah sholat, untuk mendalami sejauh mana proses bimbingan fiqih sholat khusyuk' berjalan.

\section{HASIL DAN PEMBAHASAN}

Shalat memiliki pengaruh yang efektif untuk mengobati rasa sedih dan gundah yang menghimpit manusia ketika menghadapi problematika hidup. Saat seseorang menjalankan shalat dengan khusyu' dan membebaskan dirinya dari urusan duniawi, maka jiwanya akan merasa damai dan tenang sehingga tidak akan mudah tertekan dengan beban yang ada.

Kekhusyu'an dapat menjadikan shalat memiliki peran penting dalam penyucian jiwa dan berperilaku, baik itu melalui shalat fardhu maupun shalat sunnah. Shalat yang dilakukan dengan khusyu' merupakan solusi bagi berbagai masalah kehidupan.

Dalam shalat terdapat interaksi hati dan ruh dengan Allah. Hati dan ruh menjadi dekat dengan Allah ketika seseorang mengerjakan shalat. Ia akan merasakan nikmat berdzikir dan merasa nyaman bermunajat kepada Allah. Ia akan menggunakan semua organ tubuh dan kekuatan yang dimilikinya untuk beribadah kepada Allah. Ia tidak akan larut dalam kesibukan dengan makhluk atau hal duniawi. Ia hanya akan memfokuskan hatinya untuk menjalin hubungan dengan Allah. Sehingga ia akan terbebas dari bayangan lain yang muncul ketika sedang shalat.

Pelaksanaan shalat yang tepat waktu dan sesuai dengan jadwal waktu shalat yang telah ditetapkan lima kali dalam sehari dapat melatih kedisiplinan. Seseorang akan terbiasa untuk tepat waktu dan disiplin dalam kehidupan sehari-hari. Shalat yang dibiasakan di awal waktu dan tidak lalai dengan terus menunda nya akan membentuk jiwa yang disiplin dan waspada. Ibadah shalat mendatangkan kemaslahatan dunia dan akhirat serta menolak kemudharatan dunia dan akhirat. Shalat akan mencegah pelakunya dari perbuatan dosa, mendatangkan penawar untuk hati yang sakit, menyinarihati yang gelap, menghindarkan dari berbagai penyakit fisik, membuat organ tubuh menjadi kuat, meredam gejolak hawa nafsu, mendorong orang untuk berbuat baik, dan menghindarkan kegundahan.

Melalui terapi shalat seseorang akan mendapatkan ketenangan batin karena dalam shalat ia menyerahkan seluruh urusannya kepada Allah. Shalat dapat mencegah kemungkaran karena dalam shalat seseorang senantiasa mengingat Allah dan fokus kepada Allah sehingga setelah melaksanakan shalat, hati dan perilaku seseorang akan menjadi lebih baik lagi. Ia merasa selalu diawasi oleh Allah sehingga akan menjaga tingkah lakunya.

Shalat khusyu' dapat memberikan ketenangan jiwa, meningkatkan sistem syaraf, meningkatkan daya tahan tubuh, dan menyembuhkan berbagai penyakit. Seseorang yang telah mencapai ketenangan jiwa tidak akan mudah terguncang ketika menghadapi berbagai lika-liku permasalahan kehidupan. Jiwanya akan tenang karena ia yakin dengan sepenuhnya kepada Allah.

Dapat disimpulkan bahwa ada pengaruh positif antara kekhusyu'an shalat terhadap ketenangan jiwa. Hal ini sejalan dengan pendapat Utsman Najati bahwa keadaan yang tentram dan jiwa tenang yang dihasilkan dari shalat mempunyai dampak terapeutik yang dapat meredakan ketegangan saraf, yang timbul akibat berbagai tekanan kehidupan sehari-hari dan menurunkan kegelisahan serta kecemasan.

Ditinjau dari metode ketenangan jiwa, shalat dapat berfungsi sebagai pengobatan, pencegahan, dan pembinaan. Dalam suatu terapi kejiwaan, biasanya terjadi dialog antara pasien dan konsultan. Pasien mengungkapkan perasaan, keluhan dan permasalahan dirinya kepada konsultan. Konsultan mendengarkannya, memahaminya, dan memperhatikan perasaannya serta menerimanya. Dengan cara demikian, pasien akan merasa lega karena perasaan, keluhan, dan permasalahannya didengar, dipahami, diperhatikan, dan diterima. Dalam pertemuan beberapa kali pasien akan sembuh.

Dari segi pembinaan jiwa, pelaksanaan shalat yang khusyu' serta gerakannya yang dilakukan dengan penuh ketenangan dan penghayatan, akan membentuk jiwa yang tenang. 
Penghayatan terhadap makna dan doa dalam setiap bacaan shalat yang berisi pengagungan terhadap Allah, permohonan ampunan dari segala dosa, serta permohonan rahmat dan kebaikan akan membentuk jiwa yang suci.

Ritual shalat memiliki faedah yang sangat besar. Ibadah tersebut mampu menghilangkan perasaan berdosa pada diri seseorang, memberikan kekuatan spiritual yang dapat membantu proses penyembuhan berbagai penyakit fisik dan psikis, menyingkirkan rasa takut, memberi semangat dan menerangi hati agar dapat menerima ilmu Allah.

Berdasarkan uraian tersebut, dapat disimpulkan bahwa ibadah shalat berhubungan dengan kesehatan jiwa. Shalat yang khusyu' dan ikhlas dapat mendatangkan mental yang sehat dan memberikan ketenangan pada jiwa seseorang. Shalat khusyu' mengandung aspek meditasi dan relaksasi sehingga dapat digunakan sebagai pereda stress yang dapat meningkatkan ketahanan tubuh secara natural.

Berdasarkan hasil kajian tersebut, maka menurut penulis shalat khusyu' dapat menjadi terapi jiwa, artinya dapat digunakan sebagai salah satu metode psikoterapi. Namun selain shalat hendaknya harus disertai juga dengan ibadah lain seperti zikir, puasa dan amalan lainnya. Serta yang tidak boleh dilupakan selain hubungan dengan Allah adalah hubungan baik antar sesama manusia.

Shalat adalah suatu kegiatan fisik-mental spiritual yang memberikan makna bagi hubungan antara seorang muslim dengan Allah, dengan sesama manusia maupun dengan diri sendiri. Bagi orang-orang yang beriman, shalat merupakan aktivitas yang dinanti-nantikan karena dengan shalat itu adalah ajang perjumpaan dengan Allah.

Shalat bukan hanya sekedar ritual formal, melainkan ada muatan aktual, yaitu bukti nyata yang bisa dirasakan. Shalat bukan hanya gerakan yang harus dilakukan dan sebatas kegiatan harian yang tidak bermakna, tetapi lebih dari itu ia adalah kegiatan yang besar sekali faedahnya, baik bagi kehidupan dunia maupun akhirat. Rasulullah selalu shalat apabila merasakan keraguan dalam hatinya.

Menunaikan ibadah apapun yang diwajibkan oleh Allah sesungguhnya mampu membersihkan dan menjernihkan jiwa. Jiwa yang bersih dan suci merupakan jiwa yang sehat dan tenang. Untuk mendapatkan kondisi jiwa yang seperti itu maka harus dilakukan penyucian jiwa. Dan jiwa yang suci bisa didapatkan dengan ilmu yang bermanfaat dan amal shaleh.

Melaksanakan shalat fardhu seharusnya bukan hanya untuk sekedar menggugurkan kewajiban agar tidak mendapat dosa. Saat mengerjakannya harus disertai dengan keikhlasan hati bukan karena terpaksa sehingga hanya akan menjadi beban dan tidak dapat menjadi penawar baginya.

Shalat adalah alat untuk memperbarui energi bagi orang beriman yang dapat memberikan kekuatan baru. Kepuasan sejati yang didapatkan dengan mendekatkan diri kepada Allah akan menghilangkan berbagai penyakit mental. Ketika seseorang mendapatkan kepuasan dengan mendekatkan dirinya, maka jiwanya akan merasa damai dan tentram.

Shalat yang berkualitas adalah shalat yang khusyu', yakni shalat yang dapat dirasakan manfaatnya. Nilai dan manfaat khusyu' dalam shalat sangat banyak, baik manfaat tersebut dirasakan langsung dalam kehidupan di dunia maupun berupa pahala di akhirat kelak.

Shalat khusyu' berperan dalam menekan segala bentuk stress dan depresi yang timbul akibat tekanan dan tuntutan dalam kehidupan. Dampak shalat khusyu' terhadap jiwa yakni memiliki peranan yang efisien dalam menanggulangi keraguan dan kecemasan.

Orang yang mengerjakan shalat dengan khusyu' tidak merasakan sendiri. Ia seolah sedang berhadapan langsung dan melakukan dialog dengan Tuhannya. Suasana spiritual sepert ini dapat menolong seseorang untuk mengungkapkan segala perasaan dan berbagai permasalahan yang dihadapi. Dengan demikian ia mendapatkan tempat untuk mencurahkan segala yang ada dalam pikirannya. Dengan shalat khusyu' orang akan mendapatkan ketenangan jiwa, karena merasa dirinya dekat dengan Allah dan memperoleh ampunan dari-Nya.

Seorang muslim yang shalat dengan niat yang benar dan dengan hati yang bersih maka akan mendapatkan pengaruh-pengaruh positif dalam diri, batin, sikap, perilaku dan memiliki sifat-sifat terpuji. Apabila seseorang telah melaksanakan shalat secara sempurna, khusyu' dalam shalatnya serta tulus dan ikhlas dalam pengamalannya maka shalatnya itu akan memberikan dampak positif terhadap suasana batin, kejiwaan dan psikologisnya menjadi tentram. Kondisi ini sangat mendukung bagi terbentuknya kepribadian individu yang utuh, sehat, produktif dan efektif.

Shalat dapat menghapus dosa, menyucikan jiwa dan membangkitkan jiwa untuk selalu berharap meraih ampunan dan keridhaan Allah. Hubungan manusia dengan Allah ketika menjalankan shalat dapat meningkatkan kekuatan spiritual yang memiliki pengaruh besar dalam menciptakan perubahan jiwa dan raga. Kekuatan 
spiritual dapat menghilangkan perasaan terhimpit, perasaan tidak berdaya, membangkitkan harapan, menguatkan keinginan, menghalau kekhawatiran dan rasa takut, menjaga keseimbangan jiwa, kekuatan spiritual memberi rasa tanggung jawab dalam mengemban tugas dan tujuan manusia dalam kehidupan dunia dengan baik.

Dalam psikologi, shalat dapat berfungsi sebagai terapi, hal ini disebabkan dalam shalat terdapat nilai transendental, psikologis, fisiologis dan sosial.Keyakinan dalam shalat memiliki efek penyembuhan tertentu. Penelitian menunjukkan keyakinan dalam shalat dapat menyembuhkan baik ketika orang tersebut berdoa untuk kesembuhannya sendiri maupun mendoakan kesembuhan orang lain.

Ibadah shalat memiliki pengaruh yang luar biasa untuk terapi rasa galau dan gundah dalam diri manusia. Mengerjakan shalat secara khusyu', dengan niat menghadap dan berserah diri total kepada Allah, serta meninggalkan semua kesibukan, maka seseorang akan merasa tenang, tentram dan damai.

Semakin besar kekhusyu'an seseorang maka semakin ringan pula ia mengerjakan shalat dan makin baguslah kualitas shalatnya. Ini berarti bahwa kualitas shalat menunjukkan kualitas kekhusyu'an seseorang. Sedangkan kualitas kekhusyu'an menunjukkan kualitas iman seseorang. Semakin tinggi kualitas iman seseorang maka semakin tinggi pula derajatnya disisi Allah.

Sholat khusyu' dan hadirnya rasa Bahagia memiliki keterkaitan yang erat, ditinjau dari segi psikologi agama, sholat yang dilaksanakan dengan khusyu' menempati posisi kesadaran seseorang dalam beragama, sedangkan Bahagiamerupakan hasil dari pengalaman seseorang dalam melaksanakan sholat secara khusyu'. Dimana Ketika seseorang menunaikan ibadah sholatnya dengan penuh kesadaran yang berwujud kekhusyu'an, dilapisi niat ikhlas nan tulus serta terfokus penuh pada Allah tanpa berpaling dariNya, sebagai hasil pengalamannya demikian, seseorang akan dilimpahkan rasa Bahagia dalam menjalani kehidupannya(Abdullah AS, Achyar Zein, 2017).

Sebagai bukti tela'ah tinjauan psikis, dalam suatu penelitian yang mengkaji tentang hubungan antara aktivitas kognitif saat sholat dengan variabilitas denyut jantung, menjelaskan bahwa semakin meningkat tingkat kekhusyu'an seseorang maka, akan semakin menurun pula tingkat stress seseorang. Dalam hasilnya dijelaskan bahwa setiap kenaikan satu poin tingkat kekhusyu'an dalam sholat terjadi penurunan tingkat stress sebesar 48,7 persen.
Selain itu, penelitian lainnya juga membuktikan dalam kaitannya dengan proses persalinan ibu hamil. Dalam hal ini, seringkali ditemukan emosi yang tidak stabil sehingga berakibat kecemasan menjelang proses persalinan. Kendati demikian, sholat pun ampuh menjadi jurus jitu pemberantas kecemasan, terlebih sholat yang dilaksanakan secara khusyu' mampu menghadirkan ketenangan psikis dan menghapus ketegangan, sehingga sebagai dampaknya sholat mampu menghadirkan sugesti positif bagi ibu dalam menjalani proses persalinan.

Menurut Romadhon dalam salah satu penelitiannya menjelaskan bahwa khusyu' itu sulit dan jarang terjadi, kendati demikian tetap dapat dicapai dengan awalan niat. Niat yang memiliki peran penting dalam permulaan shalat. Niat sendiri terdiri dari tiga unsur, diantaranya keinginan kuat, mencari dengan sungguhsungguh dan menjadikan hal tersebut sebagai perhatian utamanya. Dengan demikian, niat yang utuh akan membantu seseorang agar lekas khusyu' dalam menunaikan shalat. Niat beribadah tanpa menyinggung hal-hal yang lain, niat bersungguhsungguh memohon pada Sang Ilahi, niat bertunduk pasrah dan berserah pada Yang Maha Kuasa.

Hal ini kemudian akan sangat berkaitan dengan jiwa dan raga, menurut Ibn Sina jiwa dan raga memiliki koneksivitas yang erat dan akan terus bekerjasama secara kontinuitas, karena jiwa takkan pernah mampu melaksanakan perannya tanpa adanya raga itu sendiri. Jiwa menjadi sumber hidup, potensi dan pengatur progress pergerakan raga. Ibarat pilot yang masuk ke dalam pesawat lalu lekas menjadikannya bergerak dan lepas landas, untuk kemudian mengaturnya hingga sampai pada tujuan yang dituju, begitu pun dengan jiwa dan raga.

Bagi Ibnu Katsir, Shalat akan menjadi penyejuk hati bagi manusia, dengan penjelasan sekiranya shalat tersebut dilaksanakan dengan khusyu'. Beliau juga menerangkan bahwa kekhusyu'an dalam shalat hanya dapat dilaksanakan sekiranya seseorang tersebut hatinya dan pikirannya terpusat penuh pada satu titik yang dituju tanpa memikirkan hal-hal selain itu, dan menurut Ibnu Katsir hal itulah yangmenyebabkan shalat menjadi akibat kelapangan jiwanya dan kesejukan hatinya, dan inilah awal kebahagiaan tercurahkan.

Dalam ilmu psikologi, Utsman Najati menjelaskan Kesehatan mental menurut Al-Qur'an dan Sunnah dapat ditinjau dari hubungan seseorang dengan Tuhan, hubungan seseorang dengan dirinya sendiri, hubungan seseorang dengan sesamanya, hubungan seseorang dengan 
alam semesta. Mengenai hubungan seseorang dengan Tuhan sangatlah linear dengan hal ini, selagi shalat merupakan proses hubungan seseorang Tuhannya. Demikian, kesehatan mental yang baik akan mencerminkan kebahagiaan dalam dirinya.

Kebahagiaan sendiri bila ditinjau dari psikologi positif merupakan suatu cara hidup yang dapat membuat individu memenuhi segala potensinya dan mampu mengarahkan manusia ke arah kehidupan yang baik. Karenanya, ia tak hanya bergantung pada kenikmatan, kekayaan dan kepercayaan agama saja. Seringkali suatu kebahagiaan seseorang dikaitkan dengan kepuasan dlam hidupnya, maka sebagaimana dijelaskan sekiranya kebahagiaan tidak diukur dari kekayaan ataupun kenikmatan, senikmat apapun kehidupannya dan sebanyak apapun hartanya belum tentu menjamin kebahagiaan dalam dirinya.

Mengutip Sebuah kebahagiaan menurut Yasien Mohamed bukanlah kebahagiaan duniawi ataupun kebahagiaan yang hanya sebatas dunia, melainkan sebuah kebahagiaan yang lebih dari sekedar perihal dunia dan tidak bisa disetarakan dengan keduniaan. Bahkan lebih dalam beliau menjelaskan bahwa kebahagiaan benar-benar akan tercurahkan sepenuhnya setelah penimbangan amal baik dan buruk pada yaumul hisab. Yaitu ketika seseorang mendapat timbangan amal baiknya melebihi amal buruknya dan di dapatnya maqom yang ia nantikan semasa kehidupannya di dunia.

Hal ini dapat kita kaitkan dengan penjelasan sebelumya bahwa shalat berfaedah untuk mengontrol diri dari perbuatan buruk, Amal baik akan bermula dari konektivitas ia dengan Tuhannya, kita akan dapat melihatnya dalam kehidupan sehari-harinya, termasuk dengan shalat, sekalipun ia menjalaninya tapi sudahkah shalat itu mempengaruhi kehidupan sehari-harinya, dari kekhusyu'an inilah yang akan menjadi titik temunya.

Adapula al-Ghazali menambahkan bahwa kebahagiaan memiliki makna makrifat Allah di dua dunia yaitu, dunia alam yang sementara dan akhirat alam yang abadi. Menurutnya, kebahagiaan adalah suatu keadaan dimana kondisi jiwa terasa tenang dan damai tanpa hambatan sehingga menjadikannya kurang. Hal ini bisa dicapai dengan mengenali dirinya sendiri, mengetahui tujuannya diciptakan, tujuan segala esensi dalam hidupnya diadakan, darisanalah seseorang akan mengetahui Allah secara bertahap.

Terlebih pada zaman modern ini berdampak besar bagi kehidupan manusia dengan adanya krisis makna hidup serta spiritual yang hampa dan agama yang semakin hari semakin terkikis oleh perubahan masyarakat. Menampakkan titik terang bahwa manusia kian hari kian mengahadapi tantangan besar terkait kehidupan ini, maka benar adanya bila terdengar pepatah bahwa iman adalah kunci mengahadapi tantangan zaman. Meningkatkan ibadah sholat dengan kekhusyu'an dalam menjalaninya, membuka akses kemudahan menuju jalan-Nya yang benar sehingga terhindar dari krisisnya makna kehidupan karena ia tahu bahwa hidupnya untuk ibadah, tiada hampa pula spiritualnya karena selalu diisi dengan dzikir dando'a, tiada pula agamanya tergerus zaman karena ia jaga selalu dengan penuh penjagaan, kekhusyu'annya dalam menjalani akan senantiasa menjaganya.

Lebih dalam lagi Prof. Dr. HAMKA menjelaskan dalam salah satu karyanya bahwa orang yang memperoleh kebahagiaan dalam hidupnya ialah mereka yang mempunyai akal budi, yaitu mereka yang sanggup menentukan arah hidupnya, memiliki kehendak sehingga bergerak dan terus maju serta mempunyai tujuan adan citacita. Keutamaan yang lebih dari antara mereka adalah mereka yang sanggup membedakan dan tahu akan akibat yang telah ia perbuat, demikian menurutnya alInsanul Kamil. Lebih dari sekedar manusia sempurna, selagi Allah Maha Baik betul adanya, Maha Pengasih Maha Penyayang kepada segenap hamba-Nya, manusia memohon kepadaNya dan Berdo'a pula hanya kepada-Nya. Amal ibadah diterima di sisi-Nya, bahagialah ia dan beruntunglah ia di bawah naungan-Nya.

Kebahagiaan dalam islam memanglah tak bisa dinilai dengan materi karena ia bersifat metafisik, oleh karenanya keterkaitan antara yang memicu hal tersebut dengan sang jiwa sangatlah penting, yakni sholat. Hanya Yang Maha Menciptakanlah yang mampu melakukan, dalam ayat Al-Quran dijelaskan bukankah hanya dengan mengingat Allah hati menjadi tenang. Hal ini sangat relevan dengan sholat yang dalam Gerakan keseluruhannya berupa bacaan dzikir serta doa, sehingga terhindarlah dari kehampaan dan puaslah jiwanya sampai tenanglah ia merasa damai, karenanya mampu mengendalikan dirinya setelah ia tahu siapa dirinya dan siapa yang menciptakannya. Dalam surat Al-Fajr digambarkan bagi jiwa yang tenang akan Kembali pada Nya dengan hati yang puas pun diridhai-Nya hingga masuklah ia ke dalam surga-Nya, itulah Bahagia dunia akhirat. Kala di dunia tenanglah hidupnya damai hatinya tentram jiwa penuh kepuasan karena tiada hampa, karena baik selama kelakuannya di dunia patutlah baginya menduduki surga-Nya yang begitu diimpikan semua makhluk. 
Shalat memiliki berbagai manfaat bagi manusia, baik itu secara spiritual, fisik maupun psikis. Khusyu' merupakan hakikat dan keistimewaan dalam shalat, kekhusyu'an memiliki peranan yang penting dalam shalat. Walaupun tujuan utama shalat adalah untuk menyembah Allah dan menggugurkan kewajiban sebagai hamba, namun shalat memiliki banyak manfaat tambahan bagi orang yang melakukannya dengan sempurna.

Allah telah memerintahkan kita untuk meminta pertolongan melalui shalat dan sabar ketika berbagai permasalahan menghampiri dan menghantui pikiran kita hingga menyebabkan kita merasa menanggung beban yang berat. Rasulullah saw senantiasa mengerjakan shalat ketika sedang ditimpa masalah yang membuat beliau merasa tegang.

Seorang muslim harus memelihara shalatnya, menjaga waktunya dan berusaha untuk melakukannya dengan khusyu' agar mendapatkan manfaat yang maksimal dari shalat yang dilakukannya. Shalat akan menjadi hal yang sulit dan berat bagi mereka yang tidak memiliki kekhusyu'an.

Shalat yang khusyu' menyebabkan hamba memiliki hubungan yang lebih baik dengan Tuhannya. Dengan itu jiwanya menjadi lebih kuat untuk berjuang dalam hidup ini. Sehingga seseorang tidak akan mudah menyerah ketika menghadapi berbagai permasalahan.

Banyak orang yang melaksanakan shalat namun tidak mendapatkan manfaat darinya karena kurangnya kekhusyu'an ketika melaksanakannya. Orang yang telah memperoleh manfaat shalat khusyu' akan mendapatkan keberuntungan dari Allah. Ia juga akan terhindar dari golongan orangorang yang celaka karena telah melalaikan shalatnya.

Shalat memiliki pengaruh yang efektif untuk mengobati rasa sedih dan gundah yang menghimpit manusia ketika menghadapi problematika hidup. Saat seseorang menjalankan shalat dengan khusyu' dan membebaskan dirinya dari urusan duniawi, maka jiwanya akan merasa damai dan tenang sehingga tidak akan mudah tertekan dengan beban yang ada.

Kekhusyu'an dapat menjadikan shalat memiliki peran penting dalam penyucian jiwa dan berperilaku, baik itu melalui shalat fardhu maupun shalat sunnah. Shalat yang dilakukan dengan khusyu' merupakan solusi bagi berbagai masalah kehidupan.

Dalam shalat terdapat interaksi hati dan ruh dengan Allah. Hati dan ruh menjadi dekat dengan Allah ketika seseorang mengerjakan shalat. Ia akan merasakan nikmat berdzikir dan merasa nyaman bermunajat kepada Allah. Ia akan menggunakan semua organ tubuh dan kekuatan yang dimilikinya untuk beribadah kepada Allah. Ia tidak akan larut dalam kesibukan dengan makhluk atau hal duniawi. Ia hanya akan memfokuskan hatinya untuk menjalin hubungan dengan Allah. Sehingga ia akan terbebas dari bayangan lain yang muncul ketika sedang shalat.

Pelaksanaan shalat yang tepat waktu dan sesuai dengan jadwal waktu shalat yang telah ditetapkan lima kali dalam sehari dapat melatih kedisiplinan. Seseorang akan terbiasa untuk tepat waktu dan disiplin dalam kehidupan sehari-hari. Shalat yang dibiasakan di awal waktu dan tidak lalai dengan terus menunda nya akan membentuk jiwa yang disiplin dan waspada. Ibadah shalat mendatangkan kemaslahatan dunia dan akhirat serta menolak kemudharatan dunia dan akhirat. Shalat akan mencegah pelakunya dari perbuatan dosa, mendatangkan penawar untuk hati yang sakit, menyinarihati yang gelap, menghindarkan dari berbagai penyakit fisik, membuat organ tubuh menjadi kuat, meredam gejolak hawa nafsu, mendorong orang untuk berbuat baik, dan menghindarkan kegundahan.

Melalui terapi shalat seseorang akan mendapatkan ketenangan batin karena dalam shalat ia menyerahkan seluruh urusannya kepada Allah. Shalat dapat mencegah kemungkaran karena dalam shalat seseorang senantiasa mengingat Allah dan fokus kepada Allah sehingga setelah melaksanakan shalat, hati dan perilaku seseorang akan menjadi lebih baik lagi. Ia merasa selalu diawasi oleh Allah sehingga akan menjaga tingkah lakunya.

Shalat khusyu' dapat memberikan ketenangan jiwa, meningkatkan sistem syaraf, meningkatkan daya tahan tubuh, dan menyembuhkan berbagai penyakit. Seseorang yang telah mencapai ketenangan jiwa tidak akan mudah terguncang ketika menghadapi berbagai lika-liku permasalahan kehidupan. Jiwanya akan tenang karena ia yakin dengan sepenuhnya kepada Allah.

Dapat disimpulkan bahwa ada pengaruh positif antara kekhusyu'an shalat terhadap ketenangan jiwa. Hal ini sejalan dengan pendapat Utsman Najati bahwa keadaan yang tentram dan jiwa tenang yang dihasilkan dari shalat mempunyai dampak terapeutik yang dapat meredakan ketegangan saraf, yang timbul akibat berbagai tekanan kehidupan sehari-hari dan menurunkan kegelisahan serta kecemasan.

Ditinjau dari metode ketenangan jiwa, shalat dapat berfungsi sebagai pengobatan, 
pencegahan, dan pembinaan. Dalam suatu terapi kejiwaan, biasanya terjadi dialog antara pasien dan konsultan. Pasien mengungkapkan perasaan, keluhan dan permasalahan dirinya kepada konsultan.

Konsultan mendengarkannya, memahami nya, dan memperhatikan perasaannya serta menerimanya Dengan cara demikian, pasien akan merasa lega karena perasaan, keluhan, dan permasalahannya didengar, dipahami, diperhatikan, dan diterima. Dalam pertemuan beberapa kali pasien akan sembuh.

Dari segi pembinaan jiwa, pelaksanaan shalat yang khusyu' serta gerakannya yang dilakukan dengan penuh ketenangan dan penghayatan, akan membentuk jiwa yang tenang. Penghayatan terhadap makna dan doa dalam setiap bacaan shalat yang berisi pengagungan terhadap Allah, permohonan ampunan dari segala dosa, serta permohonan rahmat dan kebaikan akan membentuk jiwa yang suci.

Ritual shalat memiliki faedah yang sangat besar. Ibadah tersebut mampu menghilangkan perasaan berdosa pada diri seseorang, memberikan kekuatan spiritual yang dapat membantu proses penyembuhan berbagai penyakit fisik dan psikis, menyingkirkan rasa takut, memberi semangat dan menerangi hati agar dapat menerima ilmu Allah.

Berdasarkan uraian tersebut, dapat disimpulkan bahwa ibadah shalat berhubungan dengan kesehatan jiwa. Shalat yang khusyu' dan ikhlas dapat mendatangkan mental yang sehat dan memberikan ketenangan pada jiwa seseorang. Shalat khusyu' mengandung aspek meditasi dan relaksasi sehingga dapat digunakan sebagai pereda stress yang dapat meningkatkan ketahanan tubuh secara natural.

Berdasarkan hasil kajian tersebut, maka menurut penulis shalat khusyu' dapat menjadi terapi jiwa, sekaligus berdampak positif bagi kekhusyukan didalam sholat, artinya dapat digunakan sebagai salah satu metode psikoterapi. Namun selain shalat hendaknya harus disertai juga dengan ibadah lain seperti zikir, puasa dan amalan lainnya. Serta yang tidak boleh dilupakan selain hubungan dengan Allah adalah hubungan baik antar sesama manusia.

\section{KESIMPULAN}

Pelaksanaan bimbingan sholat khusysu' di masjid Darul Arqam berdampak sangaefektif bagi kekhusyukan jama'ah masjid, khususnya bagi jama'an yang selama ini masih kesulitan untuk mendapatkan kekhusyukan didalam sholat.
Maka bagi jama'ah yang selama ini masih merasa was-was dan tidak khusyuk di dalam sholat akaan sangat berpengaruh bagi sholatnya, dengan itu maka jam'am masjid akan bisa merasakan khusyu yang sebenarnya sebagimana Khusyu' yang dimaksud di dalam surat al-mu'minun ayat 2 adalah kesan khusus dalam hati seseorang yang sedang menunaikan shalat dengan mengerahkan seluruh fikiran dan isi hatinya untuk fokus pada bacaan shalat, memahami maknanya dan mengabaikan hal-hal selainnya. Shalat khusyu' ialah shalat yang dilakukan dengan sempurna yaitu dengan menghadirkan hati, merendahkan diri, menjadikan anggota badan tenang, menundukkan pandangan, dan memusatkan pikiran(Safrilsyah, 2013).

Dalam konteksnya shalat khusyu' sebagai terapi jiwa, yakni memposisikan shalat sebagai hal utama dalam menghadapi segala macam tuntutan dan tekanan hidup. Shalat yang khusyu' dapat dijadikan sebagai sumber ketentraman hati bagi seorang muslim. Shalat khusyu' berhubungan langsung dengan kesehatan jiwa individu. Dari segi pembinaan jiwa, pelaksanaan shalat yang khusyu' serta gerakannya yang dilakukan dengan penuh ketenangan dan penghayatan, akan membentuk jiwa yang tenang. Shalat khusyu' dapat mendatangkan mental yang sehat dan memberikan ketenangan pada jiwa. Shalat khusyu' mengandung aspek meditasi dan relaksasi sehingga dapat digunakan sebagai pereda stress yang dapat meningkatkan ketahanan tubuh secara natural.

\section{DAFTAR RUJUKAN}

Abdullah AS, Achyar Zein, S. A. (2017). Manhaj Imam An-nawawi Dalam Kitab Al-Arbain Annawawiyah: Kajian Filosofi di Balik Pnulisan Kitab Hadis Al-arba'in An-nawawiyyah. AtTahdis: Journal of Hadith Studies, 1, 30.

Arifin, M. Z. (2018). Konsep khusyuk dalam alqur'an. Tesis Sarjana.

Hidayah, N. (2021). SHALAT KHUSYU' SEBAGAI TERAPI KETENANGAN JIWA (Kajian Surat AlMu'minun A yat 2).

Hukum, K. P., Studi, P., Mazhab, P., Hukum, D. A. N., Syariah, F., Hukum, D. A. N., \& Hidayatullah, U. I. N. S. (2017). Kepastian Hukum Tentang Khusyu 'Dalam Salat Menurut Fikih ( Hukum Islam ).

Purahman, P. (2018). Salat khusyuk dalam perspektif alquran dan sains. http://digilib.uinsby.ac.id/id/eprint/26357

Romadhon, Y. A. (2019). Pengembangan Alat Ukur Khusyuk Sholat Dalam Kaitan Pengaruh Positifnya Bagi Kesehatan. MAGNA MEDICA: Berkala Ilmiah Kedokteran Dan Kesehatan, 
6(1), 88. https:// doi.org/10.26714/ magnamed.6.1. 2019.88-98

Safrilsyah. (2013). Psikologi Ibadah Dalam Islam. https://repository.arraniry.ac.id/id/eprint/12147/1/1. PSIKOLOGI IBADAH \%281\%29_merged.pdf

Salat Sebagai Media Terapi Jiwa Perspektif Tafsir Sufistik $\mathrm{Ru}>\mathrm{H}\} \mathrm{Al}-\mathrm{Ma}{ }^{\prime} \mathrm{a}>\mathrm{Ni}>$ Karya AlAlusi. (2020).

Suri, P. I. (2014). THE INFLUENCE FERVENT PRAYER TRAINING TO REDUCE PREMARITAL SEXUAL BEHAVIOR ON DATING UNIVERSITY STUDENTS. 6(2), 181-192.

Wiliyani, U. (2013). Konsep Tahajjud Dalam Perspektif Imam Ghajali. Journal of Chemical Information and Modeling, 53(9), 1689-1699.

Abdurrahman, 2012, Tafsir Al-Qur'an (5) Surat AlMu'minun-Saba, (Terjemahan Muhammad Iqbal, dkk), Jakarta: Darul Haq.

Abidin, Fadhil Zainal, 2019 Terapi Shalat Khusyuk Menarik Rezeki Bertubi-Tubi, Jakarta: Wahyu Qalbu. Al-Isfari, Abu

Muhammad, 2014, Shalat, Solusi Hidupku, Surakarta: Shahih.

Amin, Muhammad Rusli dkk., 2014, Psikologi Shalat Untuk Orang Sukses, Jakarta: AMP Press

Aqib, Zainal, 2013, Konseling Kesehatan Mental: untuk Mahasiswa, Guru, Konselor, Dosen, Bandung: Yrama Widya.

Media. Chirzin, Muhammad, 2010, Buku Pintar Asbabun Nuzul, Jakarta: Zaman.

Imran, Ali, 2011, Fiqih, Bandung: Citra Pustaka Media Perintis.

Karzon, Anas Ahmad, 2010, Tazkiyatun Nafs, (Terjemahan Emiel Threeska), Jakarta: Akbar Media.

Kurniawan, Iwan, 2015, The Miracle of Shalat, Bandung: Marja. 2015

Latifah, Ummi, 2016, Shalat Tahajjud Sebagai Media Terapi Dalam Mewujudkan Ketenangan Jiwa, Skripsi Jurusan Bimbingan dan Konseling Islam, Fakultas Dakwah dan Ilmu Komunikasi, IAIN Padang sidimpuan, Padang Sidempuan.

Purahman, 2018, Salat Khusyuk Dalam Perspektif Alquran Dan Sains, Skripsi Jurusan Ilmu Alqur'an dan Tafsir, Fakultas Ushuluddin dan Filsafat, UIN Sunan Ampel, Surabaya.

Rasyid, Sulaiman, 2010, Fiqh Islam, Bandung: Sinar Baru Algesindo

Sabiq, Sayyid. 2011. Fikih Sunnah, (Terjemahan Khairul Amru Harahap dkk), Jakarta: Cakrawala Publishing

Safrilsyah, 2013, Psikologi Ibadah dalam Islam, Banda Aceh: Naskah Aceh.
Shaleh, Moh, 2016, Terapi Shalat Tahajjud: Menyembuhkan Berbagai Penyakit, Jakarta: Mizan Publika.

Sugiyono, 2016, Metode Penelitian Kombinasi (Mixed Method), Bandung: Alfabeta.

Sulaiman, 2017, Ringkasan Fiqih Sunnah, (Terjemahan Ahmad Zaeni Dachlan), Depok: Senja Media Utama.

Sumawati, Tiara, 2020, Salat Sebagai Media Terapi Jiwa Perspektif Tafsir Sufistik Ruh Al-Ma'ani Karya Al-Alusi, Skripsi Jurusan Ilmu Alqur'an dan Tafsir, Fakultas Ushuluddin dan Filsafat, UIN Sunan Ampel, Surabaya.

Wulandari, Dewi, 2019, Perspektif Imam Al-Ghazali Tentang Amalan Shalat Sebagai Terapi Batin, Skripsi Jurusan Tasawuf Psikoterapi, Fakultas Ushuluddin, UIN Sunan Gunung Djati, Bandung.

Yusuf, Muri, 2014, Metode Penelitian Kuantitatif, Kualitatif \& Penelitian Gabungan, Jakarta: Prenadamedia Group. 